\title{
Filozofsko-religijski aspekti podudarnosti i razlika Chestertona i Guardinija
}

\author{
Bruno Matos*
}

\begin{abstract}
Sažetak
Iako filozofija religije posjeduje svoje metode i jedinstvenu strukturu istraživanja, ona se, poput ostalih filozofskih disciplina, sustavno razvija naslanjajući se na prijašnje tradicije mišljenja ukorijenjene u zasebnoj kulturi, nacionalnom identitetu i jeziku. Za razliku od "europske" ili "kontinentalne" filozofsko-religijske misli, filozofsko promišljanje o religiji u Engleskoj, i kasnije u Sjedinjenim Američkim Državama, naslonjeno je na tradiciju škotskoga pojma common-sense, empirizma i analitičko-jezične metode.

U kojoj je mjeri ta razlika prisutna može se prepoznati u djelima dvojice autora, Chestertona i Guardinija. Oba su filozofa nesumnjivo obilježila razvoj kršćanske filozofije u moderni. Chesterton je bio novinar koji je ulazio u javne polemike $s$ istaknutim znanstvenicima i književnicima svojega vremena kao što su Shaw i Huxley, a Guardini se je ipak kretao unutar teologije. U ovom se radu prije svega osvrćemo na temeljna pitanja u njihovim filozofsko-religijskim istraživanjima te ukratko izlažemo opće odrednice i interese. U drugom koraku kritički analiziramo njihove postavke s ciljem izdvajanja onih mjesta koja su različita i podudarna. Na posljetku interpretiramo kritičko-analitičke uvide kako bismo izložili one sinteze koje bi bile relevantne za suvremenu filozofiju religije. Guardini je, s obzirom na prevedena djela $i$ znanstvene članke, prisutan u našoj filozofiji, a Chestertonova je misao još nedovoljno istražena, ako se izuzmu djela i članci objavljeni tijekom katoličke obnove u Hrvatskoj kao i one novijeg datuma. Pretpostavljamo da ćemo ovim izlaganjem doprinijeti proučavanju međusobnih utjecaja filozofija religija u Engleskoj i Europi s kraja 19. i prve polovice 20. stoljeća.
\end{abstract}

Ključne riječi: Romano Guardini; Gilbert Keith Chesterton; zdravi razum; personalizam; religija; moderna; vjera

\section{Uvod}

Romano Guardini i Gilbert Keith Chesterton nesumnjivo su obogatili kršćansku misao Zapada na prijelazu iz 19. u 20. stoljeće. To je prijelomno razdoblje

* Dr. sc. Bruno Matos, Hrvatsko katoličko sveučilište. Adresa: Ilica 242, 10000 Zagreb, Hrvatska. ORCID iD: https://orcid.org/0000-0002-1126-1324.E-adresa: bruno.vtz3@gmail.com 
koje obilježava krah apsolutnih monarhija, industrijalizacija, urbanizacija, emancipacija građanskoga sloja, svanuće sekularizma i totalitarnih ideologija. U takvom ozračju Guardini i Chesterton promišljaju o različitim temama: moderni, revolucijama, utopijama, liberalizmu, individualizmu i, svakako, o odnosu teologije i prirodnih znanosti, čiji utjecaj jača i postaje sve relevantnijim u društvenom životu. Obojica "ne-akademski" filozofi, obojica zreli teoretičari s jasnim kritičkim odmakom prema suvremenosti, Guardini i Chesterton ipak se razlikuju po svojim polazištima i metodama. U ovom se radu ne zadržavamo toliko na njihovim različitostima, koje su naravno bitne, koliko na pokušaju da utvrdimo niti poveznice, koje na primjeru njihova filozofskoga stvaralaštva ukazuju na međuodnose i utjecaje angloameričke i "kontinentalne" ili europske filozofije religije na prijelazu prošlih stoljeća. Kako su Chesterton i Guardini ostavili iza sebe bogat opus djela koje se bave filozofsko-religijskim pitanjima, bilo bi preopširno izlagati sve teme, stoga smo se u ovom izlaganju usredotočili na dva važna pitanja filozofije religije na prijelazu stoljeća: pitanju svjetonazora i fenomenu religije, o kojima su dosta pisala oba autora.

\section{Romano Guardini}

Romano Guardini (1885.-1968.) njemački je teolog talijanskoga porijekla koji je iza sebe, slično Chestertonu, ostavio djela koja svjedoče o različitim kako fazama istraživanja tako i interesima. Batista Mondin $(1989,320)$ u svojem priručniku iz suvremene filozofije Guardinijev opus dijeli na tri etape: dijalektičku, personalističku i kritičku. Za Lasića $(2013,75)$ Guardini je neotomist. No je li Guardini u strogom smislu riječi neotomist ili se u promišljanju religije približava fenomenalizmu? Raguž $(2015,218)$ smatra kako se Guardini na početku svojega akademskoga bavljenja teologijom nastojao udaljiti kako od liberalne protestantske struje tako i "ustajale" katoličke školske teologije. Proizlazi kako je Guardini tražio neki srednji put između neotomizma i fenomenalizma. U ovom dijelu rada dajemo pregled triju razvojnih etapa njegova filozofskoga promišljanja o religiji: dijalektičkoj, u kojoj se bavi pitanjem religiozne predodžbe svijeta i svjetonazora; personalističkoj, u kojoj razmatra središnje mjesto osobe Isusa Krista u kršćanstvu; kritičkoj, u kojoj analizira kršćanstvo moderne.

\subsection{Dijalektička etapa: religija i kršćanski svjetonazor}

Tijekom svoje prve, dijalektičke etape, Guardini se bavi filozofskim pitanjem religije i svjetonazora, problematici kojoj je posvećena i njegova katedra na Katoličkom sveučilištu u Wrocławu (Poljska). Guardinijevo zanimanje za religiju i svjetonazor za tadašnje je prilike aktualno: prvo, jer istraživanje religije više nije rezervirano „školskoj“ katoličkoj teologiji, i drugo, katoličanstvo se kao dominantni svjetonazor na Zapadu susreo s pojavom svjetonazora koji se temelje ne toliko na filozofskoj spekulaciji koliko na argumentacijama prirodnih znanosti. Wilhelm Dilthey prepoznaje u svjetonazoru tendenciju za općim važenjem i za- 
htjevnošću, iako isto poriču povijesnost i život (Zalar, 2005, 2). Ako je kršćanstvo svjetonazor poput idealizma ili naturalizma, podrazumijeva li nadilaženje povijesnosti i života? Chesterton detektira neku vrstu deprivacije kršćanskoga svjetonazora u engleskoj kulturi, koja je generirala iz viktorijanskoga pokušaja kompromisa suprotstavljenih svjetonazora. No Guardini povezuje kritički moment identiteta katoličkoga svjetonazora s pitanjem religiozne predodžbe svijeta. Kršćanski svjetonazor nije utemeljen na poimanju prirode kao neovisnoga i sebidostatnoga mehanizma kao u naturalizmu, ne temelji se na apstrakciji stvarnosti kao sintezi fundamentalnih suprotnosti kao u idealizmu, pa posljedično i u dijalektičkom materijalizmu, nego na Objavi Trojedinoga Boga.

Svjetonazori naturalizma i idealizma ne podrazumijevaju dinamiku čovjekova odnosa prema zbilji — on je svakako doživljava, ali taj doživljaj podrazumijeva pasivnost promatrača koji istu stvarnost ne može mijenjati ni utjecati na njegovu promjenu. Kršćanski je svjetonazor formiran na religijskom vjerovanju, a religija je životna i konkretna, tako da i Weltanschauung nastoji zahvatiti cjelinu, a da pritom apstrahira istu cjelinu od njezine bitne konkretnosti, kako bi se, posljedično, izbjegla teoretska razrada koja gubi iz vida osobitost kao uvjet samoga poznavanja (Dotolo, 2019, 165). No, je li moguće konstruirati kršćanski svjetonazor kao osobito i životno gledanje svijeta ne uvažavajući pritom tomistički koncept ontološke razlike bitka i bića i, posljedično, valjanost naravne spoznaje?

Guardini smatra kako se metafizički koncept stvarnosti i svjetonazor bitno ne razlikuju jer i jedan i drugi nastoje artikulirati spoznaju svijeta u njegovu totalitetu iako drukčijim putevima: metafizika nastoji kroz teoretsko (apstrahirajuće) mišljenje povezati pojedinačno i opće, a svjetonazoru je totalitet svijeta već a priori izložen. ${ }^{1}$ Ipak, Guardini preuzima koncept ontološke strukture bitka u opravdanju integriteta kršćanskoga svjetonazora. Budući da je svjetonazorski uzet totalitet sačinjen od triju sveukupnih cjelina: Boga, svijeta i čovjeka, i kako su one ontološki različite (Zalar, 2005, 609), proizlazi kako čovjek kao religiozno biće doživljava fenomenološki zbilju kao jednu harmoničnu cjelinu, a putem racionalne spoznaje kao ontološku strukturu.

\subsection{Personalistička etapa: vjersko iskustvo osobe Isusa Krista}

Zašto je Guardiniju, tijekom personalističke etape filozofskoga istraživanja religije, važna Kristova osoba, a teologiji poslije Prvoga vatikanskoga koncila bila je važnija naravno-teološka argumentacija Objave? Ako je riječ o određenom pomaku prema personalističkomu tumačenju, ono je već bilo prisutno kod ruskih personalista Berdjajeva i Solovjeva, iako je na Zapadu problematika osobe bila

1 »Entre una y otra hay, no obstante, una profunda diferencia. La metafísica trata de aprehender la esencia en su pura universalidad, prescindiendo de si está o no realizada en una cosa concreta. La concepción del mundo, por el contrario, enfoca precisamente la esencia como realizada. La metafísica se ocupa también por supuesto del problema de la realidad, pero de una realidad en general, no de la de ésta cosa real; se ocupa del problema de la concreticidad, pero de una concreticidad en general, no de la de esta cosa en concreto.« (prev.Antonio Gómez Robledo, La esencia de la concepción católica del mundo, México, 1957.). 
prisutna u teološkoj misli još od vremena Boecija. Budući da osobni susret sa svijetom nameće dva modaliteta — jedan apstrahirajući, odnosno teoretski, i drugi konkretni ili životni, pretpostavlja se da Guardini nastoji analizirati iskustvo svetoga imajući u vidu oba aspekta, iako to nije jasno u koncipiranju religije i vjere. Guardini je za religioznu i vjersku spoznaju koristio dva etimološki različita termina: Glaubenserkenntnis ${ }^{2}$ i Religiöse Erkennentnis, što se može pripisati različitim fazama bavljenja teološko-epistemološkim pitanjima, ali također i različitim disciplinama — o vjerskoj spoznaji, Glaubenserkenntnis može se govoriti samo u teologiji, a o religioznoj, Religiöse Erkennentnis unutar filozofije i fenomenologije religije. Stoga je kod Guardinija teško razaznati govori li on o vjerskom ili religioznom iskustvu. Fenomenološko produbljivanje religioznoga iskustva udaljilo bi ga od apologetskoga i približilo ga komparativnomu pristupu, a pretpostavlja se kako je tražio jedan modalitet kompromisa, koji ga je vodio ka definiranju kršćanstva izvan tada postojećih neokantovskih i neotomističkih okvira.

U svojem eseju o biti kršćanstva Guardini ističe kako se kršćanstvo ne može svoditi na etički prerogativ ljubavi prema bližnjemu, na religiju objavljenoga i osobnoga Boga, kao ni na religiju koja je savršena i potpuno sukladna s načelima razuma. ${ }^{3} \mathrm{U}$ nastojanju da bit kršćanstva teološki suvislo iznese bez oslanjanja na teoretske postavke u tadašnjoj teologiji, Guardini analizira mjesta u novozavjetnim knjigama imajući u središtu osobu Isusa Krista — njegove riječi, djela i geste. Vjerska se spoznaja kod kršćana razvija u neposrednom odnosu s Isusom Kristom, u čemu Guardini ne zaobilazi životno iskustvo Crkve, molitvu ili liturgiju, nego se štoviše vraća na epistemološku problematiku vjerovanja u Krista kao stvarnu osobu.

Dinamizam se vjere u teološkoj antropologiji kod Guardinija odvija unutar dispozicija odstojanja i blizine (Zalar, 2005, 609). Ako vjernik mora biti drukčiji od svijeta kako bi ga u svojoj slobodi ispravno vrjednovao, on mora biti prema tomu svijetu u dispoziciji Kristove osobnosti. Utvrđivanjem personalističkoga pristupa religioznomu iskustvu, Guardini je dao odgovor na nedoumice oko kršćanskoga svjetonazora. Kršćanstvo ne može biti "samo" svjetonazor, jer počiva na vjeri kao živom odnosu osobe, svijeta i Boga u Kristu. To jest, »jedino je vjera svjetonazor. Svaki vjernik jest izvan svijeta, potpuno je drukčiji od svijeta, on je sud svijeta, kako piše naš pisac [Guardini]. U vjerniku se događa Kristova sloboda od svijeta, a opet vjernost svijetu, ljubav prema svijetu« (Raguž, 2015, 283). Izjednačavanjem vjere i svjetonazora nisu ukinute fundamentalne razlike: kršćanski svjetonazor je teoretiziranje, vjera ostaje darom milosti. Ipak, kršćanski

2 Romano Guardini objavio je knjigu o teološkoj epistemologiji Glaubenserkenntnis: Versuche zur unterscheidung und Vertiefung (Basel, 1944.), koje je usredotočeno na problematiku autentičnoga iskustva Krista u kršćanskoj zajednici.

3 »Esta enumeración podría prolongarse todavía, hasta llegar a aquellas teorías que tratan de presentar al cristianismo como la religión perfecta en absoluto, tanto por ser la más acorde con los postulados de la razón, como por ser la que contiene la doctrina ética más pura y la que en mayor grado coincide con las exigencias de la naturaleza.« (prev. Felipe González Vicen, La esencia del cristianismo, Madrid, 1945.). 
svjetonazor koji bi obuhvaćao zbilju isključivo teoretskim putem, bez oslanjanja na vjeru, postao bi ideologijom jednakoga dometa i utjecaja kao i ostale ideologije onoga vremena, i u tom aspektu pretpostavljamo da je Guardini izjednačio kršćansku vjeru i svjetonazor.

\subsection{Kritička etapa: kriza kršćanske vjere}

Guardini u svojem djelu Konac novog vijeka izlaže odrednice religioznosti u antici, srednjem i novom vijeku te donosi svoja predviđanja o religioznosti budućnosti i kako će se ona reflektirati na kršćansku praksu. Antičkoj je religioznosti svojstvena predodžba stvarnosti koja je nastanjena božanstvima i bogovima. Antički čovjek numinozno doživljava tu stvarnost, iz koje mitološki iščitava božansko počelo, arhé (Guardini, 2002, 12). Takva mitološka slika prisutna je u antičkom filozofiranju o religiji. Srednjovjekovna je pobožnost pak prožeta simboličkim odnosom prema Bogu, koji je imanentan, jer ga možemo racionalno spoznati polazeći od stvorenoga svijeta iz kojega deriviramo simbole, ali je i transcendentan, suvereno postojeći izvan svijeta (Guardini, 2002, 15). Srednjovjekovna religioznost kod kršćana predstavlja jedan prijelaz iz antičkoga, naivnoga doživljavanja svetoga prema racionaliziranju istoga iskustva.

U novom vijeku, zahvaćenom baconovskim preokretom, religiozna svijest $u$ deizmu i naturalizmu vraća se antičkomu doživljaju prirode, s time da takva otkrivena priroda mora reflektirati sposobnost čovjekove prevlasti u znanstvenoj spoznaji, izraz ljudskoga postojanja kakvo treba biti (a ne kakvo jest) (Guardini, 2002 , 42). Ako smo otklonili predodžbu prirode kao prebivališta božanstava, u čemu je srednjovjekovna religiozna svijest samo predstavljala fazu prema krajnjim implikacijama racionalizacije, faze Weberova raščaravanja, teško je oživjeti numinozno strahopoštovanje kakvo su osjećali antički ljudi. No, kako Guardini ističe, suvremenomu "poganstvu" nedostaje faktor naivnosti s kakvim su antički ljudi doživljavali ono što su u prirodi pripisivali djelovanju božanstava (Guardini, 2002, 104). Antička je naivnost prevladana u skolastičkom tumačenju zbilje te je ostala elementom romansirane poetike i proze. Guardini zato ne ulazi u sociološke ili političke analize dekristijanizacije koja zahvaća modernu. Ne treba zaboraviti kako u njegovu vremenu nema takvoga zamaha agnosticizma ili religioznoga indiferentizma na Zapadu kakvima svjedočimo danas. No Guardini je detektirao (možda i predvidio) kako suvremena kriza kršćanstva nije kriza kršćanskoga svjetonazora ili institucionalnoga djelovanja Crkve, nego kriza osobne vjere kršćana. Nalazi li Chesterton slične probleme u svojoj filozofiji religije?

\section{Gilbert Keith Chesterton}

Gilbert Keith Chesterton (1875.-1936.) nije u strogom smislu filozof religije i ne bismo trebali u njegovim razasutim razmišljanjima tražiti određeni sustav, iako je uočljiva jedinstvena metoda. Budući da iza sebe nije ostavio nijedno djelo koje bi bilo filozofski sustavno, interpretacija njegovih zbirki eseja, kao i proznih 
djela, može voditi ka pretpostavci da je Chesterton bio filozof religije čije razmišljanje pri tom ne gubi karakteristike polemike, dapače, Chesterton je » prije svega rođeni borac, koji se ne boji otvorenoga sučeljavanja« (Scott, 1912, 17). Chesterton je po pitanju odnosa kršćanstva i ostalih religija polemizirao s racionalistima, anarhistima i socijalistima. 0 njegovu stilu apologetskoga razmišljanja o kršćanstvu ne možemo toliko suditi na temelju sustavnosti, koliko na temelju koncizne uporabe teoloških i filozofskih postulata koje Chesterton koristi u svojim raspravama i esejima. Chestertona su u nas prevodili i o njemu pisali eminentni članovi Katoličke akcije. ${ }^{4}$ Svakako da su njegova djela u tom kontekstu poslužila u buđenju političkoga katolicizma na našim prostorima.

\subsection{Kršćanstvo u viktorijanskoj književnosti}

Chesterton je književni kritičar koji se zanima za viktorijansku književnost kao i svojih suvremenika (primjerice Rudyarda Kiplinga). Analizirajući viktorijansku književnost, koju je izložio na stotinjak stranica djela The Victorian Age in Literature, Chesterton ne potretira samo autore, nego i njihov odnos prema kršćanstvu. Viktorijanci romantičarskoga nadahnuća traže svoje motive u poganskoj prošlosti, a njegovi se suvremenici okreću utopijama budućnosti. I u jednih i drugih Chesterton prepoznaje neuspješan pokušaj kompromisa između suprotstavljenih koncepata slobode oličenih u idejama kršćanstva s jedne i Francuske revolucije s druge strane (Chesterton, 1946, 15). To je jedan eklektički pokušaj pomirenja kršćanskih ideala, možemo reći i svjetonazora, s idealima antike, prosvjetiteljstva, ali s idejama socijalizma, anarhizma i imperijalizma. Kako je rekao, nesreća viktorijanskih autora nije u njihovu nastojanju pomirenja hladnoga racionalizma s religioznim vjerovanjem, nego što su time pokazali fundamentalnu nedosljednost (Chesterton, 1946, 26).

Viktorijanski je kompromis okrenut prošlosti, srednjemu vijeku. Chesterton zato kritizira viktorijansko romansiranje srednjovjekovnih mistika, romansiranje koje iz svojega vida upravo gubi kristocentrični karakter takve vrste mistike, a nastoji ga izjednačiti s religioznošću Istoka. Nekima od viktorijanskih romantičara sv. Franjo sigurno je bliži zbog svojega osebujnoga odnosa prema životu i prirodi, no te sličnosti više govore u prilog samomu sv. Franji nego li Chestertonovim suvremenicima, koji su srednjovjekovni misticizam htjeli parcijalno usvojiti ne uvažavajući teološki i povijesno-kulturni kontekst. Chesterton ističe da između romantičara i sv. Franje svakako postoji paralela ekstatičnoga promatranja svijeta: mistiku životna sreća proistječe iz dubokoga vjerskoga iskustva, a pjesniku je otkriveni osjećaj sreće zapravo izvor vjere (Chesterton, 1923, 86). Drugim riječima, misticizam sv. Franje razlikuje se od romantičarskoga jer je mistično iskustvo ono iskustvo stvarnosti koja proizlazi iz iskustva Boga i takav mistični pogled na stvoreni svijet, kao i emocije koje ga prate, plod su duboke i sigurne vjere.

Stoga Chesterton ne shvaća predrasude pojedinih predstavnika tih krugova prema kardinalu Newmanu i oxfordskomu pokretu. Newman nije fanatičan 
nego konzistentan, ne toliko u filozofsko-teološkom koliko logičkom i epistemološkom smislu, jer njegova pobuna, kako tumači Chesterton, proistječe iz racionalne pobune religije nasuprot iracionalizmu viktorijanskoga kompromisa (Chesterton, 1946, 31). Eduardijanski autori pak, odbacujući kompromis svojih prethodnika i uvažavajući sve moguće sociološke i kulturološke interpretacije teorije evolucije (Browning, Tennyson, Huxley), skreću prema utopijama.

\subsection{Povijest religije i kršćansko iskustvo Boga}

Povijest religije kod Chestertona se razvija pod utjecajem pravaca filozofije religije u Engleskoj koja u 19. stoljeću ima dvije faze. Prvu čine autori koji su spajali izvorni platonizam s njemačkim idealizmom Ficthea i Schellinga, što je utjecalo na daljnji razvoj evangeličke obnove. Drugu fazu karakterizira povratak Origenu i kršćanskim platonistima, utjecaju Hegela te pokušajima obnove učenja i prakse sakramenata među evangelicima (Caldecott, 1901, 78). Utjecaj je njemačke filozofije religije neupitan, iako se na Cambridgeu razvijala škola čiji su članovi bili skloniji Platonu. Od Kanta je preuzet racionalistički epistemološki okvir, a promišljanje o religioznom iskustvu ipak je vodilo ka platonističkomu idealizmu, koji kasnije oblikuju Coleridge i Culdworth. No, kako ističe Caldecott, britanski se filozofi religije nisu čak ni poslije reformacije udaljili od skolastičkoga realizma u prirodnoj teologiji (Caldecott, 1901, 417). Kako bismo stekli okvirnu sliku o povijesti religije kod Chestertona, treba uzeti u obzir kako se Chesterton naslanja na Newmanovo razumijevanje razuma i vjere, religiozne spoznaje i vjerskoga iskustva.

Kako bi opravdao svoje približavanje tomizmu, Newman je 1845. objavio Esej o razvoju kršćanske doktrine, a 1870. djelo o filozofskoj problematici religiozne spoznaje i iskustva Gramatika pristanka. Kršćanski se nauk razvija na temelju Objave u Isusu Kristu i uz pomoć milosnoga dara vjere, pri čemu je važno mistično, a ne samo literarno čitanje Svetoga pisma (Hutton, 1905, 176), čime se Newman jasno ograđuje od racionalističkih utjecaja u egzegezi i teološkoj epistemologiji. Religiozne se spoznaje razlikuju od znanstvenih u pogledu pristanka. Znanstvene spoznaje izgrađuju jedan sustav utemeljen na izvođenju (eng. inferance) jedne spoznaje iz druge, no objektivno veća ili manja vjerojatnost istinitosti neke spoznaje ne mora utjecati na odluku osobe hoće li u nju vjerovati ili ne. Kako sam Newman ilustrira, u različitim situacijama mi se informiramo na temelju novinskih članaka, različitih osvrta i kritika, korespondencije, no njihova istinitost ili neistinitost ne ovisi o našem vjerovanju u njihov sadržaj-sve ovisi o pristanku (Newman, 1881, 173). Newman u djelu Gramatika pristanka posvećuje cijelo jedno poglavlje pitanju tvrdnji, njihova shvaćanja i možebitnoga pristanka na njihovu istinitost ili kontradiktornost. ${ }^{5}$ Drugim riječima, religiozna spoznaja o Bogu u kršćanskom teizmu, iako vrjednuje napore razuma, koji se utječe sigurno-

5 Kardinal Newman posvetio je prvo poglavlje Gramatike problematici pristanka i shvaćanja tvrdnje (propozicije). Polazi od jednostavnih primjera u kojima svaki čovjek koristi svoje epistemičke sposobnosti kako bi došao do istine koju sadrži neka tvrdnja. Prvo razmatra pojavu same tvrdnje, 
sti koju mu pružaju stupnjevi vjerojatnosti, ipak ovisi o pristanku slobodne volje osobe da prihvati ili ne prihvati sadržaj religije.

Time Chesterton pretpostavlja kako je kršćanska spoznaja Boga u tome autentična, za razliku od spoznaje svetoga ili božanskoga u drugim religijama, jer uvažava slobodu pristanka pojedinca da vjeruje u Boga i objavljene istine. Nije li to temeljni Chestertonov argument u raspravama s Huxleyjem ili Shawom? Naime, u odnosu prema Shawovim i Huxleyjevim idejama, Chesterton ne odbacuje njihove kritike kapitalizma i organizirane religije. Ne možemo zaključiti kako Chesterton u potpunosti smatra da je kršćanstvo savršeno ili je savršeno slobodno-tržišno uređenje ondašnjega britanskoga gospodarstva. Njegovi su suvremenici projicirali razvoj društva na temelju iste religiozne vjere o kakvoj upravo govori Newman. Kako bi se ostvarila savršena demokracija kakvu zamišljaju anarhisti, ili savršeni ekonomski sustav u kojem nema klasnih podjela kakav zamišljaju socijalisti, osim samoga pristanka razuma, potreban je angažman cjelokupne osobe, ali već time Chestertonovi sugovornici afirmiraju temeljnu postavku dispozicije kršćanskoga vjerovanja. Chesterton se slaže s Huxleyjem kako svijet, da bismo ga voljeli, mora biti drukčiji od nas (Evans, 1939, 18). Jer ako je taj svijet, kao u idealizmu, samo odraz naše uvjetovane spoznaje, nije "drugo". Ako je opet zasebna kompozicija dirigirana vlastitim zakonitostima kao u naturalizmu, opet je apsolutno "drugo". Ni u prvom ni u drugom konceptu nije moguća relacija između čovjeka i zbilje, ali je ona moguća u kršćanstvu.

\section{Različitosti i podudarnosti filozofije religije Guardinija $i$ Chestertona}

Chesterton je umro u svojem domu u Londonu 1936., okrijepljen sakramentima i ostavivši iza sebe bogati opus svojih članaka, eseja, drama i zbirki pjesama. Guardini je nastavio sa svojim predavanjima o kršćanskom svjetonazoru na Sveučilištu u Berlinu sve do 1939., kad mu je to bilo onemogućeno, te je bio prisiljen prihvatiti umirovljenje (Krieg, 1998, 457). Nakon što smo iznijeli neke od glavnih tema u filozofiji religije dvojice autora, u nastavku interpretiramo različitosti ali i podudarnosti koje ih zbližavaju.

\subsection{Točke razilaženja}

Koje su točke razilaženja u filozofskom pristupu religiji kod Chestertona i Guardinija? Prvo, filozofija religije kod Guardinija prolazi određene etape. Nakon prvotne zaokupljenosti dijalektičkim shvaćanjem stvarnosti, Guardini se kasnije približava problematici osobe i fenomenologiji religije. Kod Chestertona nemamo takvih etapa. Ulaskom u Katoličku crkvu Chesterton otkriva nasljeđe skolastike te njegova filozofija religije postaje apologetska i polemička. Drugo,

što svaka osoba izjavljuje o vanjskom svijetu, a u drugom se posvećuje pitanju povezanosti logičke strukture tvrdnje i načinima shvaćanja tvrdnje (Newman, 1881, 2-12). 
kod dvojice autora možemo prepoznati različite metodološke pristupe filozofskoga analiziranja religije. S jedne strane, ključni je element Chestertonova filozofskoga izlaganja o religiji aparat zdravorazumske logike, kojom se Chesterton koristi kako bi argumentirao paradoksalnost suprotnih teza. S druge strane, Guardini se u svojoj filozofiji ne bavi toliko strukturom filozofske argumentacije istina Objave kao u neoskolastici. Logička koherentnost sustava bitna je za apstrahiranje totaliteta, a Guardiniju je bitnije iskustvo totaliteta, iskustvo zbilje koje uvjetuje približavanje otajstvu Kristove osobe.

Treće, koncept kršćanskoga svjetonazora zauzima drukčija vrjednovanja kod Guardinija nego kod Chestertona. Kod Guardinija kršćanski svjetonazor podrazumijeva u isto vrijeme dominantno viđenje svijeta u prošlosti, ali i kao aktualni ishod vjernikova odnosa prema svijetu (svjetonazor je vjera!). Chesterton opisuje kršćanski svjetonazor kao romantičar, ima pred sobom prikaz nekoga predprosvjetiteljskoga uređenja, koje suprotstavlja suvremenim ideologijama svojih neistomišljenika. Guardini pretpostavlja kršćanski svjetonazor u njegovu aktualitetu pred izazovom ateizma i agnosticizma. Chesterton nalazi drukčije uzroke povlačenja kršćanskoga svjetonazora, koji leže u historicističkom vrednovanju kršćanstva. Kršćanstvo ne može biti istrošeno zato što bi nove ideje bile bolje, kako to Chesterton objašnjava na primjeru pokrštavanja Prusa, koji su se u kratkom vremenu iz katoličanstva preobratili na protestantizam. Prema tom primjeru, kršćanski ideal nije ostao neprokušan i neželjen, nego iznimno težak i neproživljen (Chesterton, 2016, 13). Kršćanstvo nije dakle povijesno premošteno, nego nije u potpunosti življeno. Za Guardinija pitanje kršćanskoga svjetonazora pitanje je integriteta osobne vjere kršćanina u odnosu na svijet, a za Chestertona je relevantno pitanje njegove "rehabilitacije" u kulturi, društvenom životu i politici sadašnjice.

\subsection{Dodirne točke}

Iako se Guardini i Chesterton razilaze u pogledu metodologije i istraživačkih pristupa, analizirajući na svojstven način kršćanstvo svojega vremena, pružili su jednu sliku o religioznosti u moderni koju obilježava stanoviti bijeg od povijesnosti i pesimistično vrjednovanje napretka. Obojica autora govore o postojanju jednoga "novoga" poganstva u moderni. U nastavku razmatramo obilježja takve religije moderne. U prvom dijelu razmatramo njezine utopističke karakteristike, a u drugom odgovaramo na pitanje zašto čovjek njihova, a možda i našega vremena odbacuje pozitivne ishode napretka stečene u prošlosti te time, više na religiozan nego li na znanstven način, kreira pesimističnu sliku o sebi, a posljedično i budućnosti.

\subsubsection{Religija u moderni: bijeg od povijesti i vjera u utopije}

U svojem odgovoru Shawu, koji je smatrao kršćanstvo religijom koja guši napredak, Chesterton odgovara kako se kršćanska teologija od svojih početaka temelji na razumu i slobodi (Chesterton, 1911,13). Iako se je taj odgovor Shawu 
činio banalnim, (stotinu godina prije Fides et a ratio Ivana Pavla II., koji govori o nužnoj međusobnoj upućenosti razuma i vjere) on implicira kako kritičari kršćanstva parcijalno interpretiraju povijest te time otvaraju prostor utopijama. Naime, Chesterton se protivi ideji evolutivnoga historicizma svojih sugovornika, prema kojoj je povijest kršćanske prošlosti Zapada divljačka i nazadna, a novim se uvjerenjima osigurava znanstveni napredak. Svakako da su povijesni opisi ropstva, nasilja u Križarskim ratovima i vjerskim sukobima stvar faktografije, no povijest se ne može svesti na faktografiju. Od povijesnih činjenica važnija je naša "psihološka povijest", unutarnja povijest naših odnosa prema stvarima, profanima ili svetima, mitološkima ili stvarnima (Chesterton, 2005, 154). Naime, povijesne činjenice mogu nam posvjedočiti je li kotač ekonomskoga i znanstvenoga razvoja išao naprijed ili natrag ako računamo na pojavu nekoga izuma koji je doprinio ekonomskomu razvoju ili nekoga zakona, no one ne mogu opisati čovjekov odnos prema svijetu i svetomu. Historicističko tumačenje povijesti u kojem su neke etape smatrane "nazadnima" a druge "naprednima" poslužilo je kritičarima religije da sve zlo prošlosti pripišu kršćanima, iako nisu time odgovorili na pitanje zašto bi njihovo viđenje budućnosti u utopijama bilo racionalnije, ako se "kršćanska" prošlost pokazala iracionalnom.

Naime, Chesterton je u svojim polemikama dokazao kako je utopija socijalista i materijalista jednako religiozna kao i kršćanstvo. Ona mora biti religiozna ako zahtijeva generalnu normativnost, što ilustrira primjerom Francuske revolucije. Francuski revolucionari nisu donijeli poredak u neuređeno društvo, nego su nametnuli jednako religiozne i metafizičke uredbe (o štovanju Razuma, kalendar i sl.) (Chesterton, 1975, 160). Ostvarenje utopije traži radikalne, ako ne i fanatične zahvate, ne razboritost. Blisko Chestertonu, i Berdjajev na primjeru boljševičke revolucije zaključuje kako su fanatična obećanja o socijalističkoj utopiji zamijenila ona umjerenijih, građanskih slojeva, koji su htjeli provoditi reforme (Devčić, 1997, 20). Utopije se mogu jedino ostvariti putem religioznoga žara, ali žara koji je krajnje iracionalan, i nespojiv sa shvaćanjem razuma u kršćanstvu. Utopije moderne su proturječne jer polaze od negiranja religije, iako u svojoj realizaciji traže upravo religiozan stav. Slična gledišta na vrjednovanje povijesti i utopijske tendencije moderne imamo kod Guardinija.

U posljednjem poglavlju svoje knjige Religion y relevazion ("Objava i religija") Guardini se osvrće na povijest religija s konstatacijom kako je povijest predodžbe o Bogu ujedno i povijest o ideji čovjeka. Povijesni se razvoji tih dviju ideja podudaraju (Guardini, 1964, 271). Slika o čovjeku nije cjelovita bez slike o Bogu, no religioznost moderne ne treba takvu povijest. Povijest monoteizma na Zapadu time je inferiorna i prevladana faza prema drukčijemu poimanju čovjeka, čovjeka koji uz pomoć znanosti ovladava prirodom. Pri tom mu ne treba Božja pomoć, milost ili vjera - on se oslanja na samoga sebe. Zato Guardini opisuje utopije moderne kao "skicirane" (Guardini, 1963, 123). One su skicirane u tom smislu, jer su konstruirane na planiranju, prognoziranju i predviđanju, koje čovjeku pružaju alati prirodnih znanosti. No utopija ostaje i dalje utopijom. Ona ostaje slikom budućnosti koja je jednako religiozna i bez službenih religija, i jednako apovijesna. 
Slično Chestertonovoj ocijeni da je darvinizam »doktrina o Istočnom grijehu « (Chesterton, 1975, 168), jer traži povratak povijesti na njezino ishodište, Adama prije njegova pada, tako i utopije moderne kod Guardinija pretpostavljaju potrebnu ravnotežu moći i odgovornosti (Guardini, 1963, 126), one odgovornosti koju je Adam imao prema stvorenomu svijetu, iako Adamu u njegovoj odgovornoj ljubavi za svijet nije bila potrebna moć.

\subsubsection{Razuman optimizam}

Svjetonazorima moderne prevladava pesimizam u kojem se čovjek, zbog pozitivističke slike stvarnosti, povlači u sebe. Religiozno iskustvo moderne iskustvo je intime, unutrašnjosti (Guardini, 1964, 50), što Chesterton primjećuje u romantiziranim djelima viktorijanskih književnika. Svijet kakvoga opisuju viktorijanci nije svijet mitske prošlosti, svijet čudovišta i bogova, nego njihov unutarnji svijet fantazije u koji bježe od surove stvarnosti, u koju prodire tehnologija i industrija koja mijenja i naličje društva. Chesterton je također romantičar, što možemo zaključiti čitajući njegova prozna djela, no njegova se nostalgija za prošlošću ne budi iz nastojanja kako bi obranio srednjovjekovnu politiku ili društveni život pred kritičarima kršćanstva, nego kako bi afirmirao srednjovjekovni pogled na čovjeka, koji je, za razliku od moderne, utemeljen na postavci optimizma. Chesterton svoj optimizam, koji je iznad svega racionalan, temelji na izjednačavanju pesimizma u moderni i srednjovjekovnoga maniheizma. Suvremeni modernisti, socijalisti i anarhisti slijede manihejski nauk jer preziru osobu, a precjenjuju znanje o svijetu, što je u suprotnosti sa skolastičkim realizmom.

Sv. Toma, suprotno modernim predrasudama, nije neki filozof mračne prošlosti, nego štoviše, filozof koji voli svijet, jer kršćanski asketizam, u čiji kontekst Shaw nepobitno smješta djelo sv. Tome, koliko god nam se činio u prošlosti manje ili više fanatičnim, nikad nije dovodio u pitanje dobrotu stvorenoga (Chesterton, 1923, 45). Ne polazi li Guardini od iste postavke? Nije li mu ta kategorija jednako bitna kao i Chestertonu? Odnos osobe i svijeta kod Guardinija je afirmativan i konstruktivan bez obzira na dominaciju pozitivističkoga mentaliteta, u kojem je stvarnost zauzela mjesto objekta znanstvenoga istraživanja i eksploatacije, te nužno podrazumijeva poimanje svijeta kao stvorenoga dobra, a samo takvo dobro, pod vidom stvorenosti uvjet je i slobode osobe. U pozitivizmu dobro je ono što je iskoristivo i spoznato, a skolastički koncept pretpostavlja drukčiju dispoziciju: stvoreno nije dobro po sebi ili zato što ga čovjek može učiniti još boljim za sebe, nego stoga što je stvoreno od savršenoga dobra, to jest Boga.

Čovjek poslije Kanta podrazumijeva kako je priroda ograničena pod aspektom znanstvene spoznaje, no ako i dalje religiozno poima svijet "kao" stvorenje, odnosno djelo, njegovo je religiozno iskustvo krajnje ambivalentno: ne rezultira očajem bez povjerenja i tjeskobom bez veselja (Guardini, 1964, 98). Upravo ta konfuzija doživljaja, njihova nejasnoća kojom moderni čovjek religiozno tumači današnji svijet i ulogu znanosti, svjedoči u prilog pretpostavci kako on ne može ostati moralno indiferentan prosuđujući svoj odnos prema prirodi i stvarnosti. $\mathrm{S}$ jedne strane, priroda nije samo predmet istraživanja ni potrošni resurs u vidu 
znanstvenoga optimizma, no s druge, nije ni stanje kaosa, zbog kojega bi čovjek trebao padati u očaj, samo zato što ga ne razumije ili ne može do kraja predvidjeti.

\section{Može li ta usporedba biti relevantna filozofiji religije?}

Iako su filozofska istraživanja Guardinija i Chestertona metodološki i sistemski različita, njihovi se interesi podudaraju u analizi moderne, točnije dva problema moderne: vrednovanju povijesti i čovjekova optimistična ili pesimistična odnosa prema svijetu. No, jesu li njihove sinteze, koliko god međusobno bliske, relevantne za suvremenu filozofiju religija? Obojica su bili upoznati s poviješću monoteizma, kao i s religijama Dalekog istoka, ali im rezultati komparativne studije religije u prošlosti nisu toliko bili bitni koliko analiza moderne. Moderna je iza nas, socijalističke utopije su se rasplinule padom Berlinskog zida 90-ih, a javnim diskursom ne dominira više sukob svjetonazora, kako je to bilo od kraja 19. i kroz prvu polovicu 20. stoljeća, što ne znači kako i dalje nisu relevantni. Zašto su nam potrebni i Guardini i Chesterton? Zašto nam je potrebna sinteza njihovih različitih promišljanja?

Pođimo prvo od povijesnoga vrjednovanja religije poslije moderne. Ako danas prevladava "realna bespovijesnost", kako je to ocijenio Joachim Ritter, zato što povijest jednostavno nije profitabilna (Oslić, 2014, 296), proizlazi kako religije i kršćanstvo pokazuju određenu "rezistentnost" na reduciranje povijesnosti. Novo poganstvo teško oživljava antičku naivnost prema zbilji, ali zato animira razočaranje. U tom smislu, analiza utopijskih ideologija moderne kod Chestertona i Guardinija može nam pomoći u filozofskom promišljanju religioznosti u društvima Zapada, točnije, kako je ona formirana pod utjecajima stanovitoga razočaranja nad neispunjenim utopijama svjetonazora moderne. Druga mogućnost pružena filozofiji religije pri aktualnom interpretiranju sinteze Chestertonova i Guardinijeva promišljanja tiče se optimizma kršćanskoga svjetonazora u vezi s odnosom čovjeka i stvorenoga.

Ako je kršćansko-katolički svjetonazor "preživio" modernu, kao i sukobe s materijalizmom i pozitivizmom, sekularizaciju i određenu "deinstitualizaciju" kršćanstva, te tako ušao u diskurs krajnje pluralnoga i heterogenoga društva 21. stoljeća, čuvajući svoje osnovne postulate, pitamo se s pravom, služi li on, u tom stanju, u kojem ga više ne obilježavaju masovnost ni trijumfalizam, u svrhu obnavljanja kršćanskoga Zapada kakav je bio, ili prevrednovanju koncepta racionalnosti. Guardini i Chesterton u tom smislu nisu nostalgičari, ali su anticipirali pitanje optimizma koje kršćanstvo može pružiti suvremenomu čovjeku s obzirom na ulogu razuma. Naime, teološki govor, pa tako i kršćanski svjetonazor, ne mogu pružiti optimizam suvremenomu čovjeku ako se oslanja na krizu razuma, na razum kao "slabu misao", koji ni uz pomoć znanstvenih otkrića ne uspijeva osigurati univerzalnu spoznaju (Tanjić, 2009, 42). Kriza je razuma slijedila nakon razočaranja moderne, razočaranja u neispunjene utopije koje je trebao realizirati znanstveno-tehnološki napredak. U takvim uvjetima post-moderne, moderna racionalnost mora vjerovati u pouzdanost, u primjenjivost svojih postupaka, zato 
mu je potrebna jaka vjera, kako opisuje Derrida (Fischer, 2010, 189). Pri tom, argumentacija kršćansko-katoličkoga svjetonazora kako je predlažu Chesterton i Guardini može poslužiti kao odgovor na takvo stanje današnjega fatalizma. Stoga nam je potreban Chesterton, jer je jakomu kršćanstvu potrebna i jaka znanost kao sugovornica. Potreban nam je i Guardini jer zreo dijalog između religije i znanosti podrazumijeva i nalaženje zajedničkih interesa u očuvanju svijeta koji je povjeren čovjekovoj odgovornosti.

\section{Zaključak}

Jedan od temeljnih predmeta filozofsko-religijskoga istraživanja su utjecaji koje su učitelji imali na svoje učenike. Platon na Aristotela, Albert na Tomu, kao i Husserl na Edith Stein. Učenici su kasnije kritički analizirali uvide svojih "učitelja", korigirali ono što su smatrali pogrešnim i nadopunjali svojim spoznajama ona mjesta u kojima su prepoznavali praznine i nedorečenosti. Chesterton i Guardini sigurno nisu gajili takav odnos učitelja i učenika, nemamo dokaza o njihovoj korespondenciji ni referencije koje bi svjedočile u prilog izravnoga utjecaja. Nama je bilo bitno u ovom radu istaknuti kako su Chesterton i Guardini unijeli u filozofiju religije modele teoretskoga promišljanja drukčije od uvriježenih pristupa u neoskolastici i fenomenologiji. Uvidi iz njihovih analiza povijesti religije i pesimističnih svjetonazora moderne isprepleću se i podudaraju u onim točkama koje su bitne tada kao i danas. Iako pripadaju različitim tradicijama filozofskoga promišljanja o religiji i koriste različite metode, Chestertona i Guardinija zbližava kritika moderne, koja se razvija u svjetlu krize kršćanstva i izazova znanstveno-tehnološkoga razvoja. Sinteza njihovih promišljanja je u tom smislu aktualna za današnju filozofiju, jer nam može pomoći u analizi suvremenoga poimanja racionalnosti poslije entuzijazma moderne te kako je ona bitna za današnji položaj kršćanstva na Zapadu.

\section{Literatura}

Caldecott, Alfred (1901). The Philosophy of Religion in England and America. London: Methuen and Co.

Chesterton, Gilbert Keith (1908). Heretics. London: The Bodley Head.

Chesterton, Gilbert Keith (1911). The Future of Religion: Mr. G. K. Chesterton Reply to Mr. Bernard Shaw. Cambridge: Cambridge Daily News.

Chesterton, Gilbert Keith (1923). St. Francis of Assisi. London: Hodder and Stoughton.

Chesterton, Gilbert Keith (1946). The Victorian Age in Literature. London: Oxford University Press.

Chesterton, Gilbert Keith (1975). Ortodoxia. Santiago de Chile: Gabriela Mistrad.

Chesterton, Gilbert Keith (2005). Vječni čovjek. Split: Verbum.

Chesterton, Gilbert Keith (2016). What Is Wrong With the World. Internet Archive. URL: https://archive.org/details/WhatIsWrongWithTheWorld-G.K.Chesterton/page/n2/ mode/1up 
Devčić, Ivan (1997). Nada i kriza novovjekovnih utopija. Riječki teološki časopis, 5(1), 13-20.

Dotolo, Carmelo (2019). Kršćanski Weltanschauung i etika kod Romana Guardinija. $\mathrm{Cr}$ kva u svijetu, 54(2), 163-175.

Evans, Maurice (1939). G. K. Chesterton. Cambridge: Cambridge Univeristy Press.

Fischer, Peter (2010). Filozofija religije. Zagreb: Naklada Breza.

Guardini, Romano (1963). El poder. Madrid: Ediciones Guadarrma.

Guardini, Romano (1964). Religion y revelacion. Madrid: Ediciones Guadarrma.

Guardini, Romano (2002). Konac novoga vijeka. Split: Verbum.

Guardini, Romano (Antonio Gómez Robledo, México, 1957). La esencia de la concepción católica del mundo. URL: https://guardini.wordpress.com/la-esencia-de-la-concepcion-catolica-del-mundo/ (22.06.2020.)

Guardini, Romano (Felipe González Vicen, Madrid, 1945). La esencia del cristianismo. URL: https://guardini.wordpress.com/la-esencia-del-cristianismo/ (22.06.2020.)

Hutton, Richard Holt (1891). Cardinal Newman. Boston: Houghton, Mifflin and Co.

Krieg, Robert A. (1998). Romano Guardini's Theology of Human Person. Theological Studies, 59, 457-474.

Lasić, Hrvoje (2012). Filozofija i fenomenologija religije. Zagreb: Filozofsko-teološki institut Družbe Isusove.

Lončarević, Vladimir (2019). Recepcija G. K. Chestertona u hrvatskoj katoličkoj periodici 1921.-1945. Obnovljeni Život, 74(1), 57-70.

Mondin, Battista (1989). Corso di storia della filosofia: La filosofia contemporanea: moderna e postmoderna. Milano: Massimo.

Newman, John Henry (1881). An Essay in Aid of a Grammar of Assent. London: Burn and Oats.

Oslić, Josip (2014). Filozofija i duhovnih znanosti: S posebnim osvrtom na djelo W. Diltheya. Filozofska istraživanja, 34(3), 279-297.

Raguž, Ivica (2015). Kršćanski-katolički svjetonazor prema Romanu Guardiniju. Diacovensia, 23(3), 277-291.

Scott, William Thompson (1912). Chesterton and Other Essays. Cincinnati: Jennings and Graham.

Tanjić, Željko (2009). Teologija pred izazovima sadašnjeg trenutka. Zagreb: Kršćanska sadašnjost.

Zalar, \uro (2005). Susret vjere i svijeta: Doprinos Romana Guardinija načelu korelacije. Bogoslovska smotra, 75(2), 601-628. 
The Philosophical-Religious Aspects of the Similarities and Differences between Chesterton and Guardini

\section{Bruno Matos*}

\section{Summary}

In this exposition we have attempted to compare the thoughts of Chesterton and Guardini with the intention of better understanding the different interpretation of Anglo-American and Continental traditions in the philosophy of religion of the West during the late 19th and early 20th centuries. In the first and second sections we have briefly described the work and interests of these authors and in the third and fourth made a critical analysis of certain subjects in the philosophy of religion which, at the same time, bring them close to each other and divide them. Although Chesterton is familiar with Neo-Scholasticism, in his polemic discussions he uses the pragmatic and common-sense approach to questions concerning the history of religion, and the appearance of positivism and evolutionism, which is the main difference in relation to Guardini who is closer to phenomenalism. Although Chesterton and Guardini are representatives of different traditions and different methodologies, one theme brings them together: a critique of modernity developing in light of the crisis in Christianty and scientific advancement which tells us that their personal insights are not quite as far from one other as one may surmise.

Key words: Romano Guardini; Gilbert Keith Chesterton; common sense; personalism; religion; modernity; faith

* Bruno Matos, Ph.D., Catholic Univeristy of Croatia. Address: Ilica 242, 10000 Zagreb, Croatia. E-mail: bruno.vtz3@gmail.com 